\title{
Oxidative stress and histopathological changes induced by methylthiophanate, a systemic fungicide, in blood, liver and kidney of adult rats.
}

\author{
Ben Amara Ibtissem ${ }^{1 ¥}$, Ben Saad Hajer ${ }^{2 ¥}$, Hakim Ahmed ${ }^{2 ¥}$, Elwej Awatef ${ }^{1}$, Kallel Choumous ${ }^{3}$, \\ Boudawara Ons ${ }^{4}$, Zeghal Khaled Mounir ${ }^{2}$, Zeghal Najiba ${ }^{1}$
}

1. Animal Physiology Laboratory. Sfax Faculty of Sciences. BP1171, 3000 Sfax. University of Sfax. Tunisia.

2. Laboratory of Pharmacology, Faculty of Medicine, 3029 Sfax, University of Sfax , Tunisia.

3. Hematology Laboratory, CHU Habib Bourguiba 3029. Sfax University. Tunisia.

4. Anatomopathology Laboratory, CHU Habib Bourguiba 3029. Sfax University. Tunisia.

$¥$ : These authors contributed equally to this work

\begin{abstract}
:
Background: Methyl-thiophanate (MT), a fungicide largely used in agriculture throughout the world including Tunisia, protects many vegetables, fruits and field crops against a wide spectrum of fungal diseases. Oxidative stress has been proposed as a possible mechanism involved in MT toxicity on non-target organism.

Methods: In the present study, the effect of MT injected intraperitoneally to adult rats at $300 \mathrm{or} 500 \mathrm{mg} / \mathrm{kg}$ of body weight was studied on blood, liver and kidney.

Results: Our results showed 3 days after MT injection, a significant decrease in hemoglobin and hematocrit values. A disruption in total white blood cells and platelets also occurred.

Accordingly, an increased in malondialdehyde, $\mathrm{H}^{2} \mathrm{O}^{2}$ and advanced oxidation protein levels in liver and kidney were noted with the two doses. A significant change in plasma biomarkers and organ enzymatic and non-enzymatic activities were observed after MT treatment. The modifications in biochemical parameters were substantiated by histopathological data.

Conclusion: These data confirmed the pro-oxidant effects of this fungicide. Accordingly, care must be taken to avoid mammalian and human exposure to MT.

Keywords: Methyl-thiophanate, white blood cells, red blood cells, liver, kidney.

DOI: https://dx.doi.org/10.4314/ahs.v17i1.20

Cite as: Ibtissem BA, Hajer BS, Ahmed H, Awatef E, Choumous K, Ons B, Mounir ZK, Najiba Z. Oxidative stress and histopathological changes induced by methylthiophanate, a systemic fungicide, in blood, liver and kidney of adult rats. Afri Health Sci. 2017;17(1): 154-163. https:// dx.doi.org/10.4314/abs.v17i1.20
\end{abstract}

\section{Introduction}

Extensive application of pesticides is usually accompanied with environmental pollution and health hazards. It is established that many pesticides, in common use, can produce some toxic and adverse effects on the liver, kid-

$$
\begin{aligned}
& \text { Corresponding author: } \\
& \text { Zeghal Najiba, } \\
& \text { Animal Physiology Laboratory, Life } \\
& \text { Sciences Department, Sfax } \\
& \text { Faculty of Sciences, BP1171, } \\
& 3000 \text { Sfax, Tunisia. } \\
& \text { Tel.: +216 } 74274600 ; \\
& \text { Fax: +216 } 74274437 . \\
& \text { E-mail address: najiba.zeghal@tunet.tn } \\
& \text { / naj_zgh@yahoo.fr }
\end{aligned}
$$

ney and other biological systems through their mode of action or by production of free radicals which damage exogenous cell components and alternate the antioxidant status or free radical scavenging enzyme system ${ }^{1}$.

Among pesticides, fungicides are used for food protection and in crops production with suitable quality and quantity used providing a viable economic return. Like other pesticides, fungicides are widely sprayed on agricultural land like wine-growing areas. Furthermore, residues of fungicides agrochemicals can remain on crops after the harvest and even after some food processing operations, being a major exposure pathway. Methyl-thiophanate (MT) is a benzimidazole class of fungicide known to be carcinogenic to humans ${ }^{2}$. Its application in vivo increases the incidence of skin pituitary papilloma and hepatocellular adenomas $^{3}$. Oxidative stress might play a role in MT-in- 
duced toxicity as suggested by the increased production of reactive oxygen species (ROS) and lipid peroxidation ${ }^{4}$. ROS is normally produced via the redox cycling of oxygen metabolism in living organisms having a function in the protection of the cell from pathogens ${ }^{5}$. However, over production of ROS causes the harmful damages to macromolecules in the cell such as proteins, lipids, carbohydrates, and nucleic acids. Consequently, oxidative damage disturbs physiological homeostasis, increased susceptibility of organisms to diseases and reduced reproduction ability. As a response, organisms have developed defense systems consisting of antioxidant enzymes which composed of superoxide dismutase (SOD), catalase (CAT),glutathion peroxidase (GPx) and glutathione S-transferase, and non-enzymatic components which are primarily composed of glutathione (GSH) and vitamins $\mathrm{C}, \mathrm{E}^{6}$. Although extensive research has been conducted on the effects of MT on thyroid and reproductive system 7,8 , a few studies has been done on blood and organs of detoxification but the mechanisms of its toxicity remained scarce, and there was a lack of information about its adverse effects on target tissues. The present study pertained to analyse the effect of this fungicide at graded doses (300 and $500 \mathrm{mg} / \mathrm{kg}$ b.w) on biochemical and histological aspects of blood, kidney and liver tissues.'

\section{Material and methods}

\section{Animals and experimental design}

Wistar male rats weighing about $170 \pm 10 \mathrm{~g}$, obtained from the Central Pharmacy (SIPHAT, Tunisia), were housed in plastic cages with acclimate-controlled facility and a constant light dark cycle at a temperature of $22 \mathrm{oC}$ \pm 2 and humidity of $40 \%$.

LD50 of MT was evaluated $(1000 \mathrm{mg} / \mathrm{kg})$ in our previous study4. Rats were randomly, divided into three groups of 8 animals each: rats of group 1 (control group) received oil corn injection used as vehicle; group 2 received intraperitoneally (i.p.) $300 \mathrm{mg} / \mathrm{kg}$ bw of MT and group 3 received $500 \mathrm{mg} / \mathrm{kg}$ bw of MT.

The experimental procedures were carried out according to the Natural Health Institute of Health Guidelines for Animal Care and approved by the Ethical Committee of Sfax Sciences Faculty. All animal procedures were conducted in strict conformity with the "Institute ethical committee guidelines" for the Care and Use of laboratory animals.'

\section{Blood and organ preparation}

At the end of experiment, some blood samples were collected in heparined tubes.

Plasma was then separated from blood by centrifugation at $3500 \mathrm{rpm}$ for $10 \mathrm{~min}$ and served to determine biochemical parameters. Other blood samples were collected into EDTA tubes for determination of hematological parameters and erythrocytes fragility.

Liver and kidney were quickly removed, cleaned from the adhering tissue. Then $300 \mathrm{mg}$ of each organ were homogenized using phosphate buffer (100 mM Na²HPO4/ $\mathrm{NaH}^{2} \mathrm{PO} 4, \mathrm{pH}$ 7.4) with an Ultra Turrax homogeniser in ice-cold and centrifuged at 10,000 $\mathrm{xg}$ for $15 \mathrm{~min}$ at $4^{\circ}$ C. The resulting supernatants were used for various biochemical assays. Other samples of liver and kidney were immediately fixed in $10 \%$ formalin solution for histological studies.

\section{Biochemical assays \\ Determination of hematological parameters}

WBC, red blood cells (RBC), hematocrit (Ht), hemoglobin $(\mathrm{Hb})$, mean corpuscular volume (MCV), mean corpuscular hemoglobin $(\mathrm{MCH})$ and mean corpuscular hemoglobin concentration (MCHC) were analyzed by an electronic automate Coulter MAXM (Beckman Coulter, Inc, Fullerton, California, USA).

\section{Erythrocyte fragility assay}

Osmotic fragility of erythrocytes was determined in terms of lysis in hypotonic saline solution using by the method of Godal and Heisto?. The absorbance was measured spectrophotometrically at a wavelength of $540 \mathrm{~nm}$. C50 (the osmolarity causing $50 \%$ of hemolysis) was determined and the percentage of hemolysis 99 for each sample was then 100 calculated using the following formula:

$\%$ hemolysis= (optical density of test solution/ optical density of standard solution) x100

\section{Achievement of blood smear}

A drop of fresh blood was spread on a slide, then fixed with May Grunwald for 2 minutes, and rinsed with water. After that, Giemsa was used for staining. Different blood cells and platelets were visualized using optical microscope at magnification (x100). 


\section{Liver and kidney protein quantification}

Protein contents in organs were measured using to the method of Lowry et al $^{10}$ with bovine serum albumin as standard.

\section{Liver and kidney parameters of oxidative stress}

The extent of lipid peroxidation by measuring thiobarbituric acid reactive substances (TBARS) in terms of malondialdehyde (MDA) formation was measured according to the method of Draper and Hadley ${ }^{11} .0 .5 \mathrm{ml}$ of tissue supernatant was mixed with $1 \mathrm{ml}$ of trichloroacetic acid solution and centrifuged at $2500 \mathrm{xg}$ for $10 \mathrm{~min}$. The resulting supernatant $(0.5 \mathrm{ml})$ and one milliliter of a solution containing $0.67 \%$ thiobarbituric acid (TBA) were incubated for $15 \mathrm{~min}$ at $90^{\circ} \mathrm{C}$ and then cooled. The mixture was measured for absorbance at $532 \mathrm{~nm}$ using a spectrophotometer (Jenway UV-6305, Essex, England). The malondialdehyde values were calculated using 1,1,3,3-tetraethoxypropane as standard and expressed as nmoles of malondialdehyde/mg of protein.

Hydrogen peroxide $\left(\mathrm{H}^{2} \mathrm{O}^{2}\right)$ measurementwas carried out by the ferrous ion oxidation xylenol orange (FOX1) method $^{12}$. The FOX1 reagent consisted of $25 \mathrm{mM}$ sulphuric acid, $250 \mu \mathrm{M}$ ferrous ammonium sulphate, 100 $\mu \mathrm{M}$ xylenol orange and $0.1 \mathrm{M}$ sorbitol. Briefly, $100 \mu \mathrm{l}$ of extract was added to $900 \mu$ l of FOX1 reagent vortexed and incubated during $30 \mathrm{~min}$ at room temperature. Solutions were then centrifuged at $12.000 \mathrm{xg}$ for $10 \mathrm{~min}$, the amount of $\mathrm{H}^{2} \mathrm{O}^{2}$ in the supernatant was determined using a spectrophotometer at $560 \mathrm{~nm}$. $\mathrm{H}^{2} \mathrm{O}^{2}$ levels were expressed as $\mu$ moles $/ \mathrm{mg}$ protein.

Advanced oxidation protein product (AOPP) levels were determined according to the method of Witkoet $\mathrm{al}^{13}$. Briefly, $0.4 \mathrm{ml}$ of tissue extract was treated with $0.8 \mathrm{ml}$ phosphate buffer (0.1 M; pH 7.4). After $2 \mathrm{~min}, 0.1 \mathrm{ml}$ $1.16 \mathrm{M}$ potassium iodide $(\mathrm{KI})$ were added to the tube followed by $0.2 \mathrm{ml}$ of acetic acid. The absorbance of the reaction mixture was immediately recorded at $340 \mathrm{~nm}$. The concentration of AOPP for each sample was calculated using the extinction coefficient of $261 \mathrm{~cm}^{-1} \mathrm{mmol}^{-1}$ and the results were expressed as micromoles per milligram of protein.

Superoxide dismutase (SOD) activity was estimated according to Beauchamp and Fridovich ${ }^{14}$. The reaction mixture contained $50 \mu \mathrm{l}$ of the tissue homogenate in Tris $\mathrm{Hcl}$ buffer (pH 7.8), $13 \mathrm{mM}$ L-methionine, $75 \mu \mathrm{M}$ Nitro Blue Tetrazolium (NBT), $0.1 \mathrm{mM}$ EDTA, and $2 \mu \mathrm{M}$ riboflavin. The developed blue color of the reaction was measured at $560 \mathrm{~nm}$. Units of SOD activity were expressed as the amount of enzyme required to inhibit the reduction of NBT by $50 \%$ and the activity was expressed as units/mg of protein.

Glutathione peroxidase (GPx) activity was measured according to Flohe and Gunzler ${ }^{15}$. GPx catalyzes the oxidation of reduced glutathione by cumene hydroperoxide. In the presence of nicotinamide adenine dinucleotide phosphate reduced form (NADPH) and reduced glutathione reductase, the disulfide reduced glutathione is immediately converted to the reduced form with a concomitant oxidation of NADPH. Briefly, $200 \mu$ l of the homogenized tissue were added to $200 \mu \mathrm{l}$ of the reduced 148 glutathione reductase $(4 \mathrm{mM})$ and $100 \mu \mathrm{l}$ of $100 \mathrm{mM}$ phosphate buffer, $\mathrm{pH}$ 7.4. In the presence of nicotinamide adenine dinucleotide phosphate reduced form (NADPH), the oxidized reduced glutathione is immediately converted to the reduced form with a concomitant oxidation of NA$\mathrm{DPH} / \mathrm{NADP}^{+}$. The absorbance was measured in 340 $\mathrm{nm}$. The enzyme activity was expressed as nmol of GSH disulphide/min/mg protein.

Kidney glutathione (GSH) was determined by of Ellman's method ${ }^{16}$ modified by Jollow et $\mathrm{al}^{17}$ based on the development of a yellow color when DTNB (5,5'-dithiobis-2-nitrobenzoic acid) was added to compounds containing sulfhydryl groups. In brief, Five hundred microliters of tissue homogenate in Tris Hcl buffer were added to $3 \mathrm{ml}$ of $4 \%$ sulfosalicylicacid. The mixture was centrifuged at $3500 \mathrm{xg}$ for $10 \mathrm{~min}$. Ellman's reagent was added to five hundred microliters of supernatants. The absorbance was measured at $412 \mathrm{~nm}$ after $10 \mathrm{~min}$. Total GSH content was expressed as $\mu \mathrm{g} / \mathrm{mg}$ of protein.

Vitamin C content was determined spectrophotometrically by dinitrophenyl-hydrazine method described by Jacques-Silva et al18. Briefly, ascorbic acid in the kidney tissue extract was oxidized by $\mathrm{Cu}^{2+}$ to form dihydro-ascorbic acid, which reacts with acidic 4-dinitrophenyl hydrazine to form a red hydrazone. Color development was achieved with $65 \%$ sulfuric acid, and the absorbance was measured at $540 \mathrm{~nm}$. A calibration curve was prepared using ascorbic acid as standard, and results were expressed as microgram/milligram protein.

\section{Biochemical markers in plasma}

Plasma levels of creatinine, uric acid, urea, bilirubin, aspartate aminotransferase (AST) and alanine aminotrans- 
ferase (ALT) were measured by colorimetric methods using commercial reagent kits (References: 20151, 20091, 20143, 20102, 20094, and 20012, respectively) purchased from Biomaghreb (Ariana. Tunis. Tunisia).

\section{Histological studies}

Some liver and kidney samples, served for histological studies by light microscopy, were immediately fixed in $10 \%$ of formalin solution and processed in a series of graded ethanol solutions. Organs were then embedded in paraffin, serially sectioned $(3 \mu \mathrm{m})$ and stained with hematoxylin-eosin (H-E). Six slides were prepared from each organ. All sections of liver and kidney organs were evaluated for the degree of injury.

\section{Statistical analysis}

The data were analyzed using the statistical package program Stat view 5 Software for Windows (SAS Institute, Berkley, CA). Statistical analysis was performed using one-way Analysis of Variance (ANOVA) followed by Fisher's Protected Least Significant Difference (PLSD) test as a post hoc test for comparison between groups. All values were expressed as means \pm S.D. Differences were considered significant if $\mathrm{p}<0.05$.

\section{Results}

\section{Hematological parameters}

Compared with the control group, RBC number was reduced by 14 and $16 \%, 3$ days after MT injection at graded doses 300 and $500 \mathrm{mg} / \mathrm{kg}$ b.w., respectively (Table 1).

\begin{abstract}
Table 1: Hematological parameters in control and treated rats with graded doses of MT during 3 days. RBC: red blood cells, WBC: White blood cells, Hb: hemoglobin, Ht: Hematocrit, MCV: mean corpuscular volume, MCH: mean corpuscular hemoglobin, MCHC: mean corpuscular hemoglobin concentration.

\begin{tabular}{|c|c|c|c|c|c|c|c|c|}
\hline Parameters & RBC & WBC & $\mathbf{H b}$ & Ht & MCV & МСН & МСНC & Platelets \\
\hline $\begin{array}{c}\& \\
\text { treatments }\end{array}$ & $\left(10^{6} / \mu L\right)$ & $\left(10^{3} / \mu \mathrm{L}\right)$ & $(\mathrm{g} / 100 \mathrm{ml})$ & $(\%)$ & $\left(\mathrm{mm}^{3} / \mathrm{RBC}\right)$ & (pg/RBC) & $(\mathrm{g} / 100 \mathrm{ml})$ & $\left(10^{3} / \mathrm{mm}^{3}\right)$ \\
\hline
\end{tabular}

Other hematological parameters were decreased like $\mathrm{Hb}$ (-8 and $-12 \%$ ) and $\mathrm{Ht}(-13$ and $-16 \%$, respectively). MCV, $\mathrm{MCH}$ and $\mathrm{MCHC}$ concentrations remained unchanged. A significant increase in total WBC and plateletsnumber $(+18 ;+36 \%)$ after treatment with $300 \mathrm{mg} / \mathrm{kg}$ bw dose but a decrease was occurred with $500198 \mathrm{mg} / \mathrm{kg}$ bw dose $(-40 ;-39 \%)$, compared to those of controls (Table 1).

\section{Effect of MT on erythrocytes osmotic fragility}

3 days after MT injection at graded doses 300 and 500 $\mathrm{mg} / \mathrm{kg}$ b.w., a significant increase in the percentage of erythrocytes fragility was obtained, compared to the control group (Figure 1).

\section{Blood smears}

For rats treated with MT at a dose $300 \mathrm{mg} / \mathrm{kg}$ b.w., an increase of lymphocyte and platelet numbers was noted. Inversely, at a dose of $500 \mathrm{mg} / \mathrm{kg}$ b.w. a decrease of lymphocyte and platelet numbers was occurred (Figure 1). Blood smears of rats treated with doses 300 and $500 \mathrm{mg} /$ $\mathrm{kg}$ bw confirmed the hematological findings. 
(A)

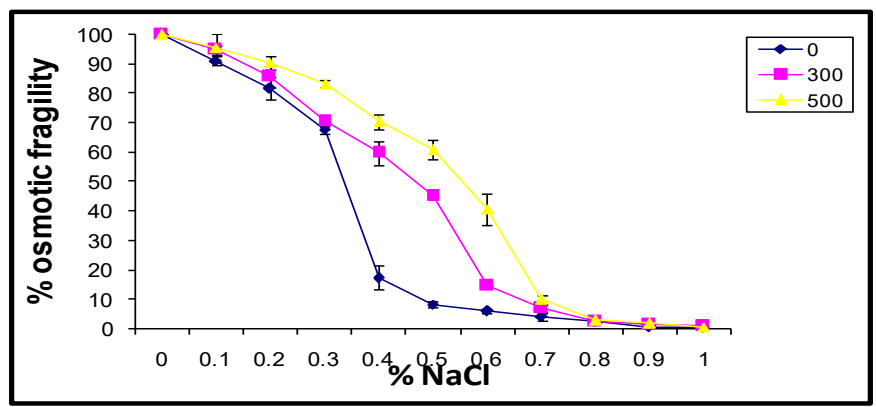

(B)

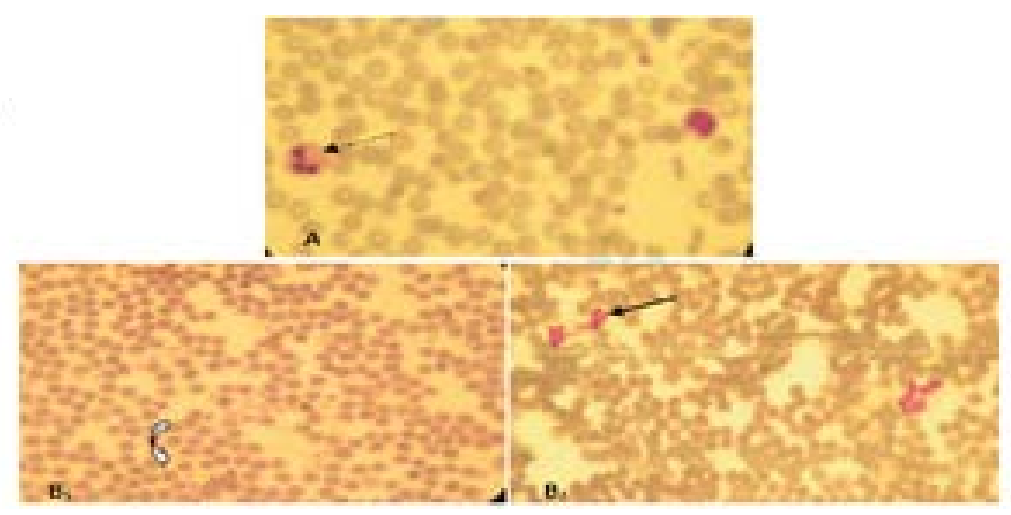

Figure 1: (A) Evolution of erythrocyte osmotic fragility and (B) blood smear in adult rats, controls and treated with300 (B1) and 500 (B2) $\mathrm{mg} / \mathrm{kg}$ b.w of MT.

$$
\underset{\text { Lymphocytes }}{\longrightarrow} \text { platelet }
$$

\section{Estimation of MDA, $\mathrm{H}^{2} \mathrm{O}^{2}$ and AOPP levels}

Our results revealed an increase of LPO, ROS production and protein oxidation levels in the liver and kidney of the MT-treated group as evidenced by the enhanced MDA $(+13 \% ; 37 \%), \mathrm{H}^{2} \mathrm{O}^{2}(+41 \%)$ and $\mathrm{AOPP}(+44$;
$77 \%$ ) levels of adult rats treated with $300 \mathrm{mg} / \mathrm{kg}$ b.w., when compared to controls (Table 3). The levels of MDA $(+26 \% ; 49 \%), \mathrm{H}^{2} \mathrm{O}^{2}(+60 \% ; 43 \%)$ and AOPP (+ 65; $78 \%)$ of adult rats treated with the highest dose $(500 \mathrm{mg} /$ kgb.w.) were also significantly increased (Table 2).

Table 2. Liver and kidney oxidative stress parameters of controls or treated rats with grade doses of MT during 3 days

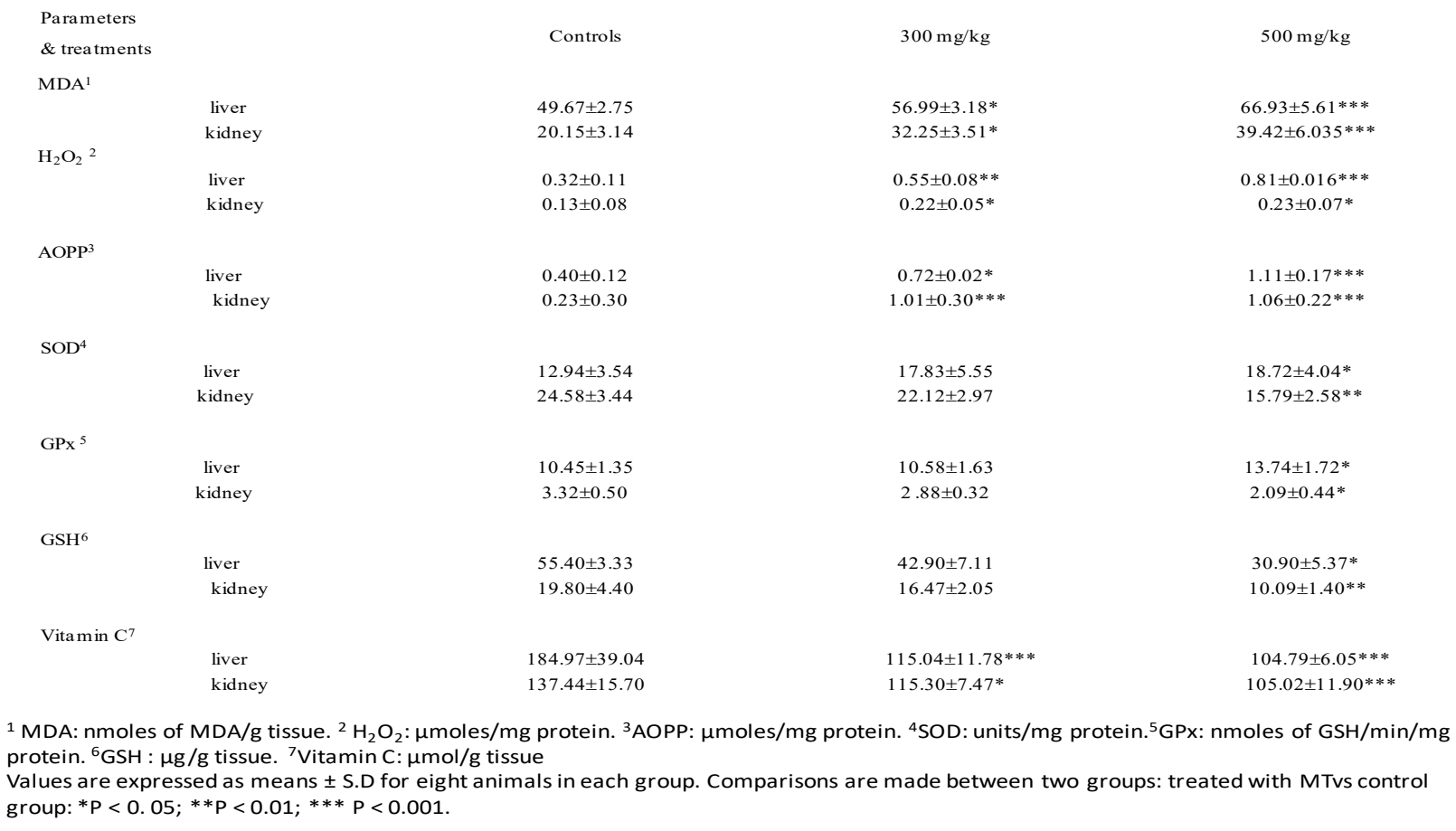




\section{Enzymatic and non-enzymatic antioxidant status}

Activities of GPx and SOD increased significantly 222 in the liver ( +24 and $+31 \%$, respectively) and decreased in the kidney homogenates ( -37 and $-36 \%$,respectively) of MT treated group with $500 \mathrm{mg} / \mathrm{kgb} . w .$, when compared to those of controls (Table 2).

A significant decrease in liver $(\mathrm{p}<0.001)$ and kidney $(\mathrm{p}<0.05 ; \mathrm{p}<0.001)$ GSH and vitamin $\mathrm{C}$ values, respectively, was evident in the MT group compared to those of controls (Table 2).

\section{Plasma biomarkers levels}

Compared to the controls, bilirubin, AST and ALT levels in MT-treated group were increased in plasma of adult rats $(\mathrm{p}<0.01)$, indicating hepatotoxicity (Table 3).

Our results also showed a constellation of disorders in the renal function of the MT treated group. In fact, Plasma creatinine and urea levels in the MT-treated rats were higher $(p<0.01)$ than those of controls (Table 3$)$. Uric acid levels were lower $(\mathrm{p}<0.001)$ in the MT treated group than those of controls (Table 3).

Table 3.Plasma biomarker parameters of controls or treated rats with MT grade doses during 3 days.

\begin{tabular}{|c|c|c|c|c|c|c|}
\hline $\begin{array}{l}\text { Parameters \& } \\
\text { treatments }\end{array}$ & $\begin{array}{c}\text { ASAT } \\
(\mathbf{U} / \mathbf{I})\end{array}$ & $\begin{array}{c}\text { ALAT } \\
(\mathbf{U} / \mathbf{I})\end{array}$ & $\begin{array}{c}\text { Bilirubin } \\
\text { (mg/L) }\end{array}$ & $\begin{array}{c}\text { Creatinine } \\
(\mathrm{mmol} / \mathrm{L})\end{array}$ & $\begin{array}{c}\text { Urea } \\
(\mathrm{mmol} / \mathrm{L})\end{array}$ & $\begin{array}{l}\text { Uricacid } \\
(\mathrm{mg} / \mathrm{L})\end{array}$ \\
\hline Controls & $66.5 \pm 6.64$ & $36.16 \pm 9.36$ & $0.20 \pm 0.01$ & $20.51 \pm 2.16$ & $7.01 \pm 0.23$ & $253.17 \pm 45.02$ \\
\hline \multirow[t]{2}{*}{ MT(300 mg/kg) } & $86.91 \pm 20.15$ & $46.37 \pm 5.44$ & $0.39 \pm 0.05$ & $23.58 \pm 3.18$ & $9.71 \pm 1.53$ & $210.72 \pm 20.56$ \\
\hline & $* *$ & $* *$ & $* *$ & $*$ & $*$ & $* *$ \\
\hline \multirow[t]{2}{*}{ MT (500 mg/kg) } & $108.20 \pm 21.67$ & $62.12 \pm 10.45$ & $0.40 \pm 0.05$ & $29.70 \pm 1.73$ & $12.12 \pm 1.83$ & $162.78 \pm 19.97$ \\
\hline & $* * *$ & $* * *$ & $* * *$ & $* *$ & $* *$ & $* * *$ \\
\hline
\end{tabular}

\section{Histopathological studies}

In the MT-treated rats with graded doses (300 and 500 $\mathrm{mg} / \mathrm{kg}$ ), liver and kidney histological pictures showed numerous abnormalities (Figures 2 and 3).

Light microscopic examination showed a liver normal structure in controls, with distinct hepatic cells, sinusoidal spaces, and a central vein (figure $2 \mathrm{~A}$ ). While with MT treatment at graded doses, histopathological changes were observed. MT caused necrosis, infiltration of inflammatory leucocyte cells and hepatocyte vacuolization (Figure $2 \mathrm{~B}$ and $2 \mathrm{C}$ ). 

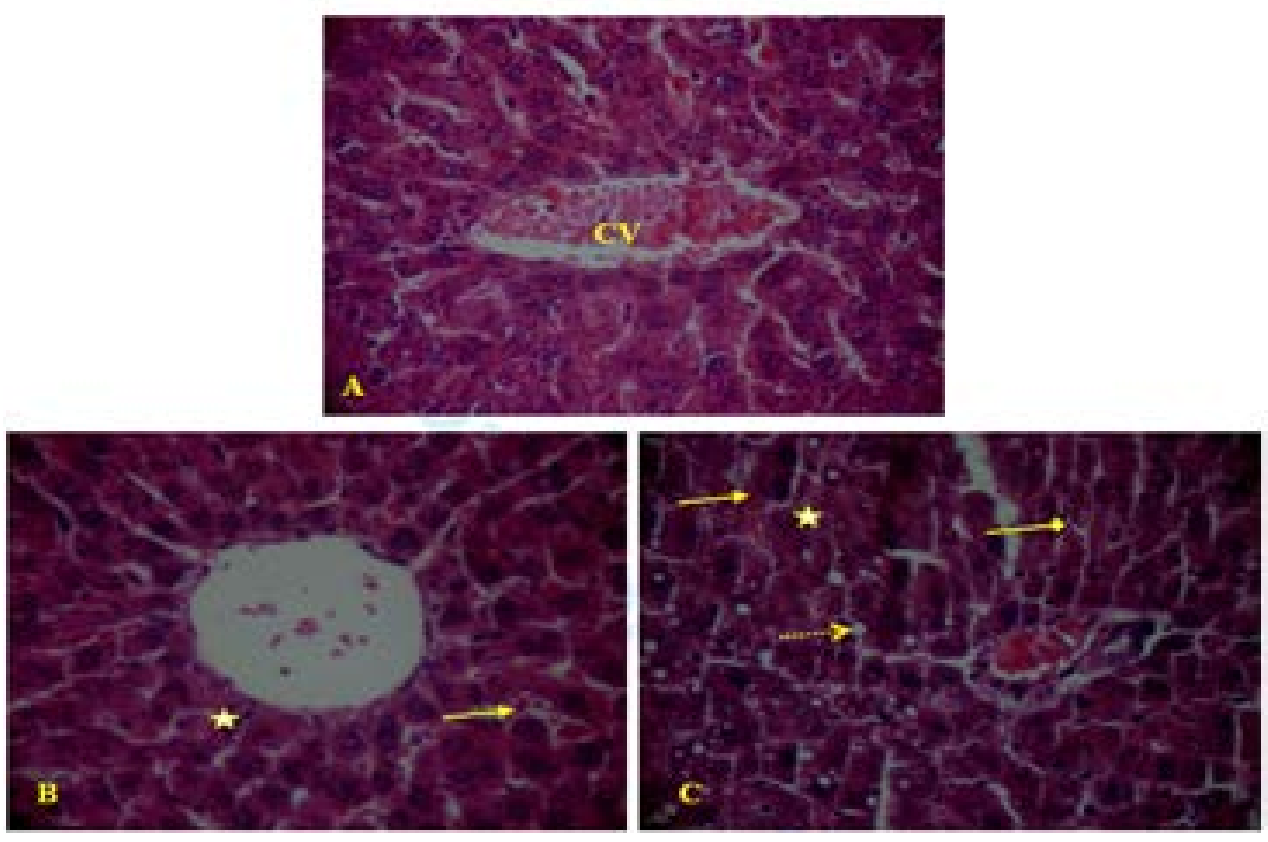

Figure 2: Liver paraffin section photograph(s) of adult rats controls and experimental groups controls (A), MT (300 mg/kg) (B), MT (500 mg/kg) (C) showing the histopathological changes.

Arrows indicate:

\section{$\longrightarrow$ Leukocyte infiltration, ....... steatosis, $\quad \hat{\alpha}$ apoptosis}

A normal cellular architecture observed in kidney of con- infiltration of lymphocyte and polynuclear cells occurred trols (figure 3A). In MT treated rats, their kidney exhibit- particularly between tubules. Furthermore, convoluted ed a narrowed Bowman's space and vascular congestion tubules were dilated showing vacuoles formation, indiinside glomeruli and between tubules (Figure 3B). The cating the beginning of a necrosis step (Figure 3C).
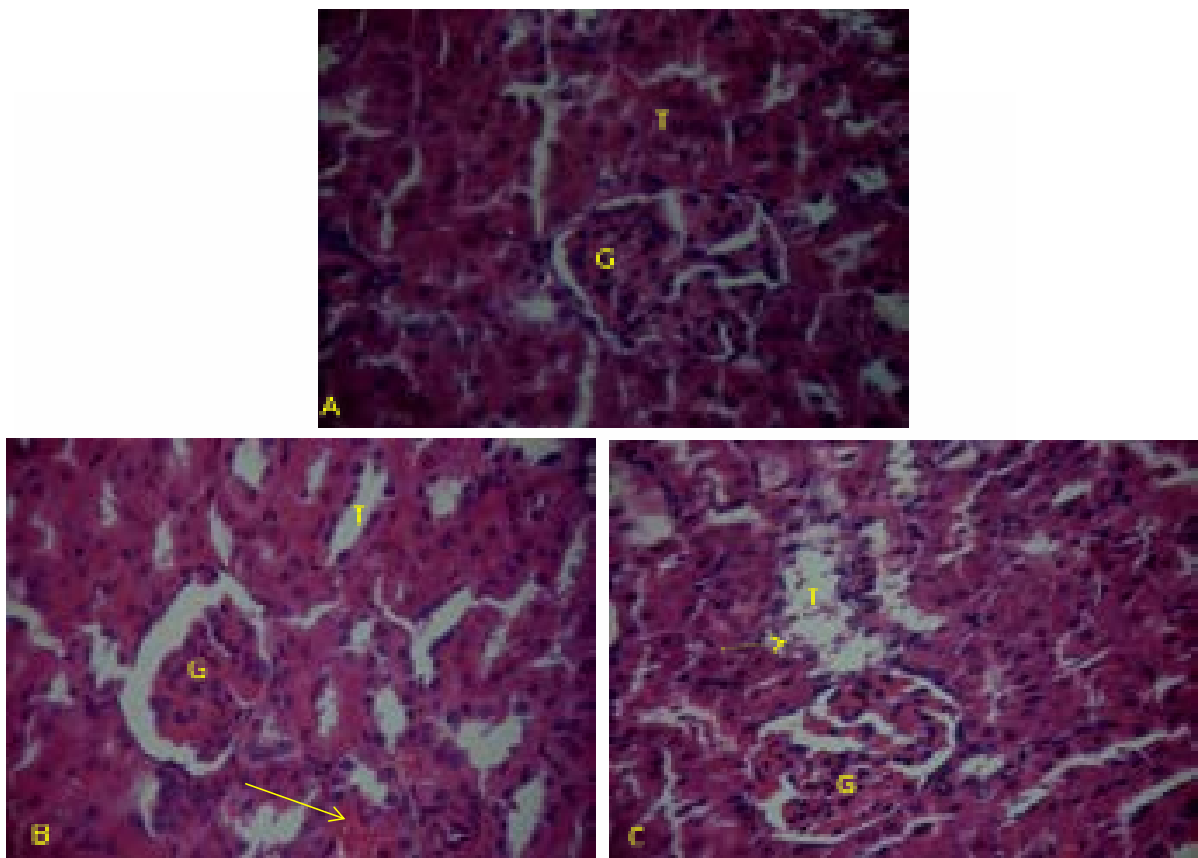

Figure 3: Kidney paraffin section photograph(s) of adult rats controls and experimental groups, showing the histopathological changes. T: tubule

G: glomeruli

$\longrightarrow$ : vascular congestion

$\cdots \cdot . . .>$ : vacuolization 


\section{Discussion}

Among important organism responses, hematological parameters provide an excellent basis for judgment of disease, extent of tissue damage, response of defence antioxidant mechanism, diagnosis of anemia and as an index to characterise health status ${ }^{19}$. Moroever, the most important organ in the biotransformation of xenobiotics is the liver. It contains high levels of enzymes and other compound which metabolize drugs. It takes up xenobiotics from the blood ${ }^{20}$. The Kidney is mainly responsible for their excretion. The aim of the present study is to examinate thecytotoxic effects of MT on hematological parameters, liver and kidney.

Our data showed abnormalities in some blood cell parameters of MT-treated rats, showed by a significant reduction in $\mathrm{RBC}$ number, $\mathrm{Ht}$ and $\mathrm{Hb}$ concentration after injection of MT at the two doses used 300 and $500 \mathrm{mg} /$ $\mathrm{kg}$ bw. This could be due to the oxidative stress probably generated by MT. Oxidative damage of erythrocytes membrane has been implicated in hemolysis. An increase of erythrocytes fragility hemolysis, as shown by us confirmed the MT-induced hemolysisand an oxidative damage to RBC. MT also disturbed the immune function of treated rats after 3 days injection with graded doses.

WBCs increased in rats treated with $300 \mathrm{mg} / \mathrm{kg}$ dose, indicating a defense reaction.

Conversly, WBCs decrease occured with the higher dose ( $500 \mathrm{mg} / \mathrm{kg}$ ) could be explained by the failure of immune system and/or the increase of leukocyte necrosis or apoptosis. The platelet count showed a significant increase 272 in the group treated with MT at $300 \mathrm{mg} / \mathrm{kg}$ and inversely a significant decrease with $500 \mathrm{mg} / \mathrm{kg}$ treated dose, when compared to controls, which could be explained by the bone marrow disorders.

Generally, liver and/or kidney abnormalities are very common in patients with primary hematological diseas$\mathrm{es}^{21}$. In the present study, the increased oxidative stress was marked by the enhanced TBARS (thiobarbituric acid reactive substances) production in the liver and kidney of MT treated rats indicating MT pro-oxidant effects to alter membrane integrity and fluidity.

Many xenobiotics, such as pesticides, are known to induce oxidative damage through ROS generation and can alter the antioxidants status or free oxygen radical scavenging enzyme systems. In fact, our study demonstrated the susceptibility of MT to generate $\mathrm{H}^{2} \mathrm{O}^{2}$ levels which can react with susceptible biological macromolecules causing therefore LPO and protein oxidation ${ }^{22}$. In the current work, oxidative protein damage may be one of the most putative mechanisms of MT induced tissue toxicity, as demonstrated by the increase of AOPP levels in the liver and kidney.

Usually the harmful effects of oxidative stress are counteracted by natural defense mechanisms that involve antioxidants enzymes. In our experiment, the activity of SOD and GPxare significantly elevated in the liver and significantly decreased in the kidney with $500 \mathrm{mg} / \mathrm{kg}$ dose. It can be suggested that the enhancement of the antioxidant defense is a normal response to increase the detoxification process in the liver ${ }^{23}$. The decrease which occured in the kidney indicated that free radicals production exceeded the capacity of detoxification mechanisms in this organ. This fact, the disruption in total antioxidant capacity in liver and kidney and the high LPO level, indicatedliver and kidney oxidative stress damage caused by MT.

According to previous findings ${ }^{24}$, non-enzymatic antioxidants can also prevent the uncontrolled production of free radicals or inhibit their reaction with biological system. GSH plays a major role in maintaining intracellular redox state and acts as antioxidant by detoxifying toxic xenobiotics. The GSH depletion enhanced LPO and the increase of $\mathrm{H}^{2} \mathrm{O}^{2}$ production could indicate the strong oxidative stress generated by MT in liver and kidney.

Vitamin C, a water soluble antioxidant, is effective in scavenging free radicals ${ }^{25}$. It acts as two electron reducing agent and confers protection by the contribution of an electron to reduce free radicals, therefore, neutralizing these compounds in the extra-cellular aqueous environment prior to their reaction with biological molecules. Moreover, the antioxidant potential of vitamin $\mathrm{C}$ is not only attributed to its ability to quench free radicals, but also to its ability to regenerate other non-enzymatic antioxidant molecules, such as vitamin E, GSH and carotene $^{26}$. Our results showed a significant decrease in the level of vitamin $C$ after MT treatment with the highest dose used, leading to the increased susceptibility of the tissues to free radical damage and thus explaining the significant decrease in GSH levels.

ALT and AST, the biomarkers of hepatic toxicity, are increased after MT administration. They are released into 
serum in proportion to cellular damage and the highest increase is observed in the acute phase of cellular necrosis. The highest level of each enzyme in plasma of MT groups clearly indicated oxidative damage with hepatocellular necrosis and an increase in permeability of plasma membrane as observed by others ${ }^{27}$. Also MT hepatotoxicity was evidenced, in the present study, by an increase of bilirubin levels resulting either from hemolysis or the decreased liver uptake, conjugation. All these changes were supported by histopathological observations in the liver tissue. Indeed, the histopathological data revealed increases in degeneration of nuclei and the presence of inflammatory leukocyte infiltration, which were more pronounced in the MT-treated groups. Furthermore, convoluted tubules were dilated showing vacuoles formation, indicating the beginning of a necrosis step.

On the other hand, the increased urea and 321 creatinine levels at 300 and $500 \mathrm{mg} / \mathrm{kg}$ treated doses might suggest renal damageas demonstrated by the observation of histopathological findings. In the current study, the creatinine and the urea levels in plasma was increased in MT-treated groups compared with the controls. The uric acid level in the plasma was significantly decreased after exposure to MT, speaking in favour of a Glomerular Filtration Rate decline. The histological findings confirmed biochemical results. In fact, we have found an infiltration of leucocytes in kidney confirming the inflammatory responses to MT treatment. Renal lesions were also characterized by tubular dilatation, an enlarged Bowman space and a vascular congestion.

\section{Conclusion}

Our data indicate, for the first time, that graded doses of MT (300 and $500 \mathrm{mg} / \mathrm{kg}$ bw) revealed hematotoxic effects, nephrotoxicity and hepatoxicity. In addition, plasma biomarker parameters were affected. The cytotoxic effect of MT was revealed by an increase in $\mathrm{H}^{2} \mathrm{O}^{2}$, AOPP production and LPO levels.These data confirmed the pro-oxidant effects of this fungicide.Accordingly, care must be taken to avoid mammalian and human exposure to MT.

\section{Acknowledgments}

The present work was supported by DGRST grants (Direction Générale de la Recherche Scientifique et Technique-Tunisie. Appui à la Recherche Universitaire de base UR/12 ES-13).

\section{References}

1. Saulsbury MD, Heyliger SO, Wang K, Johnson DJ. Chlorpyrifos induces oxidative stress in oligodendrocyte progenitor cells. Toxicology. 2009; 259: 1-9.

2. Proposed Guidelines for Carcinogen Risk Assessment. Office of Research and Development US Environmental Protection Agency. Vol. 79. EPA/600/P- 92/003C. Washington, DC: Fed Regis. 1996; 17960-51.

3. Methyl-thiophanate Revised Report of the Hazard Identification 347 Assessment. Reciew of Incomeand Wealth. 2000; 1-29.

4. Ben Amara I, Ben Saad H, Cherif B, Elwej A, Lassoued S, Kallel C, Zeghal N. Methyl350 thiophanate increases reactive oxygen species production and induces genotoxicity in rat peripheral blood. Toxicology Mechanisms and Methods. 2014; 24: 679-87.

5. Li AH, Na BK, Ahn SK, Cho SH, Pak JH, Park YK, Kim TS,. Functional expression and characterization of a cytosolic copper/zinc-superoxide dismutase of Spirometraerinacei. Parasitology Research. 2010; 106: 627-635.

6. Gutteridge JM, Halliwell B. Free radicals and antioxidants in a historical look to the future, Ann. N. Y. Academic Sciences. 2000; 899: 136-147.

7. Maranghi F, Macr1 C, Ricciardi C, Stazi AV, Rescia M, Mantovani A. Histological and histomorphometric alterations in thyroid and adrenals of CD rat pups exposed in utero to methyl thiophanate. Reproductive Toxicology. 2003; 17:617-623.

8. Traina ME, Fazzi P, Macrì C, Ricciardi C, Stazi AV, Urbani E, Mantovani A. In vivo studies on possible adverse effects on reproduction of the fungicide methyl thiophanate. Journal of Applied Toxicology. 1998; 18: 241-248.

9. Godal HC, Heisto H. High prevalence of increased osmotic fragility of red blood cells among 364 Norwegian blood donors. Scandinavian Journal of Haematology. 1981;27: 30-34.

10. Lowry OH, Rosenbrough NJ, Farr AL, Protein measurement with the Folin phenol reagent. Journal of Biological Chemistry.1951; 193: 265-275.

11. Draper HH, Hadley M. Malondialdehyde determination as an index of lipid peroxidation. Methods of Ensymology. 1990; 86: 421-431.

12. Ou P, Wolff SP. A discontinuous method for catalase determination at near physiological concentrations of $\mathrm{H} 2 \mathrm{O} 2$ and its application to the study of $\mathrm{H} 2 \mathrm{O} 2$ fluxes within cells. Journal of Biochemistry andBiophysis Methods, 1996; 31: 59-67.

13. Witko V, Nguyen AT, Descamps-LatschaB.Microti- 
ter plate assay for phagocyte-derived taurine 373 chloramines. Journal of Clinical Laboratory Analysis. 1992; 6: 4753.

14. Beauchamp C, Fridovich I. Superoxydedimutase: improved 374 assays and an assay applicable to acrilamide gel. Analytical Biochemistry. 1971; 44: 276-287.

15. Flohe L, Gunzler WA,. Assays of glutathione peroxidise. Methods of Enzymology. 1984; 105: 377 114-121.

16. Ellman G. Tissue sulfhydryl groups. Arch BiochemBiophys, 195982: 70-77.

17. Jollow DJ, Mitchell JR, Zamppaglione Z, Gillette JR, Bromobenzene induced liver necrosis. Protective role of glutathione and evidence for 3,4-bromobenzene oxide as the hepatotoxic metabolites. Pharmacology. 1974; 11: 151157.

18. Jacques-Silva MC, Nogueira CW, Broc LC, 2001. Diphenyldiselenide and ascorbic acid changes deposition of selenium and ascorbic acid in liver and brain of mice. Pharmacology and Toxicology; 88: 119-144.

19. Albers GAA, Gray GD, Jamb LF, Le Barger IA and Barker JSF,. The effect of Haemonchuscontortus infection on haematological parameters in young Merino sheep and its significance for productivity. Animal Production science. 1990. 50: 99-109.

20. Guengerich FP. Effects of nutritive factors on metabolic processe involving bioactivation and detoxication of chemical. Annual Review of Nutrition.1984; 4: 207-231. 21. Pieri G,Theocharidou E, Andrew K. Liver in haematological disorders Best Practice \& Research Clinical Gastroenterology. 2013; 27: 513-530

22. Shi H, Sui Y, Wang X, et al. Hydroxyl radical production and oxidative damage induced by cadmium and naphthalene in liver of Carassiusauratus. Comparative Biochemistry and Physiology C. 2005; 140: 115-16.

23. Valko M, Leibfritz D, Moncol J, Cronin MT, Mazur M, Telser J. Free radicals and antioxidants in normal physiological functions and human disease. The International Journal of Biochemistry and Cell Biology. 2007; 39: 44-84.

24. Zama D, Meraihi Z, Tebibel S, et al. Chlorpyrifos induced oxidative stress and tissue damage in the liver, kidney, brain of fetus in pregnant rats: the protective role of the butanolic extract of Paronychieargentea L. 2007.

25. Padayatty SJ, Katz A, Wang Y, Eck P, Kwon O, Lee $\mathrm{JH}$, et al. 401 Vitamin $\mathrm{C}$ as an antioxidant: evaluation of its role in disease prevention. Journal of American College of Nutrition.2003; 22:18-35.

26. Evans P, Halliwell B. Micronutrients oxidant, antioxidant status. British Journal of Nutrition. 2001; 85: 67-74. 27. Sharma MK, Kumar M, Kumar A. Ocimum sanctum aqueous leaf extract provides protection against mercury induced toxicity in swiss albino mice. Indian Journal of Experimental biology. 2002; 40: 1079-1082. 